\title{
Abuse of Dominance by High-Technology Enterprises: A Comparison of U.S. and E.C. Approaches
}

\section{Citation}

Scherer, Frederic M. 2010. Abuse of Dominance by High-Technology Enterprises: A Comparison of U.S. and E.C. Approaches. HKS Faculty Research Working Paper Series, RWP10-029, John F. Kennedy School of Government, Harvard University.

\section{Published Version}

http://web.hks.harvard.edu/publications/workingpapers/citation.aspx?Publd=7347

\section{Permanent link}

http://nrs.harvard.edu/urn-3:HUL.InstRepos:4448883

\section{Terms of Use}

This article was downloaded from Harvard University's DASH repository, and is made available under the terms and conditions applicable to Other Posted Material, as set forth at http:// nrs.harvard.edu/urn-3:HUL.InstRepos:dash.current.terms-of-use\#LAA

\section{Share Your Story}

The Harvard community has made this article openly available.

Please share how this access benefits you. Submit a story.

\section{Accessibility}




\section{Abuse of Dominance by High- Technology Enterprises: A Comparison of U.S. and E.C. Approaches Faculty Research Working Paper Series}

\section{F.M. Scherer}

Harvard Kennedy School

\section{J une 2010, Revised: August 2010 RWP10-029}

\footnotetext{
The views expressed in the HKS Faculty Research Working Paper Series are those of the author(s) and do not necessarily reflect those of the John F. Kennedy School of Government or of Harvard University. Faculty Research Working Papers have not undergone formal review and approval. Such papers are included in this series to elicit feedback and to encourage debate on important public policy challenges. Copyright belongs to the author(s). Papers may be downloaded for personal use only.
} 


\title{
ABUSE OF DOMINANCE BY HIGH-TECHNOLOGY ENTERPRISES:
} A COMPARISON OF U.S. AND E.C. APPROACHES*

\author{
F. M. Scherer \\ Harvard University \\ August 2010 Revision
}

\begin{abstract}
European Community competition policy has advanced by leaps and bounds since it was first authorized in the 1957 Treaty of Rome. Recently it has moved to the frontier of difficulty: dealing with alleged abusive conduct by enterprises dominating the hightechnology fields in which they operate. The most prominent thrusts are the cases involving Microsoft and Intel. This paper examines and compares the approaches taken by the United States, a veteran of high-technology competition actions, and the European Commission in their handling of the Microsoft and Intel challenges.
\end{abstract}

\section{Microsoft}

Microsoft presented the first set of challenges, addressed initially by U.S. authorities. ${ }^{1}$ I begin with some background. Created in the 1970 s to write software for primitive early personal computers, Microsoft leapt to prominence by being chosen to provide a borrowed operating system, MS/DOS, for the IBM personal computer introduced in August 1981. Up to that time, personal computers were regarded as little more than hobbyists' toys. IBM's entry into the PC field gave them business legitimacy, precipitated rapidly increasing sales, and as applications software writers targeted their creations first toward the IBM PC and the MS/DOS operating system it embodied, a snowball effect ensued. On the theory, see Katz and Shapiro (1994). By far the largest number of applications were written for the MS/DOS operating system, leading most personal computer buyers to choose a system, either from IBM or numerous imitators, resting upon MS/DOS. This "applications barrier to entry" helped Microsoft gain the lion's share of the PC operating system market. The main challenger was Apple with its Macintosh, launched at demand-limiting premium prices with a revolutionary graphical user interface (GUI) in 1984. Asked by Apple to write applications software for Macintosh, Microsoft learned the Mac's internal architecture and launched its own GUI operating system, Windows 1.0, in November 1985. Versions of Windows up to the year 2000 operated atop an MS/DOS foundation, and so Microsoft was able to offer users both backward compatibility with

*This paper is an expansion of an address presented at the Technical University of Milano on May 28, 2010.

1 . There is of course a huge literature. My approach is based upon Scherer (1996, Chapter 7); Offenhauer and Scherer (1999); and Scherer (2008). 
their old software and the advantages of GUI. But the early versions were clunky and crash-prone. Not until May 1990 did Microsoft succeed in offering an attractive version of Windows, Windows 3.0, and from that time on, Microsoft dominated personal computer operating system markets overwhelmingly.

Microsoft, however, had a vulnerability. During the first two decades of personal computing, the dominant model was for applications programs to be stored within the desktop box. When the World Wide Web first became publicly accessible during the mid1990s, it was accessed from desktop computers by means of another applications program, a browser, the most important of which, Netscape Navigator, was widely distributed beginning in late 1994. See Figure 1. But Microsoft soon saw that the alternative model characterized by Figure 2 threatened its dominant position. A user might employ a browser to access applications programs located on a server anywhere on the World Wide Web. And almost simultaneously, Sun Microsystems introduced a new potentially universal programming language, Java, whose compiler could be placed on any computer. An applications writer was able to write its program not specifically for Windows but for Java, and if such programs proliferated on the World Wide Web, users would be freed from their reliance upon Windows-based applications and could therefore equip their desktop computers with operating systems -- perhaps skeletal -- other than Windows.

Microsoft perceived this threat in 1995, licensed a browser from a company that had evolved from the same University of Illinois base as Netscape Navigator, and offered the browser, renamed Internet Explorer, as a separate free complement to its Windows operating systems. At nearly the same time it approached the leaders of Netscape and offered them financial assistance conditional upon their writing Navigator only for old versions of Windows and not for the new Windows 95 introduced in August 1995. Netscape refused Microsoft's offer and was threatened that Microsoft would "cut off their air supply." Microsoft did take retaliatory action, delaying until October 1995 the provision of interface information Netscape needed to make their Navigator software fully compatible with Windows 95. Internet Explorer thereupon moved ahead of Navigator in software magazine quality ratings and began to challenge Navigator for market share. To blunt the Figure 2 threat even more, Microsoft agreed to offer a fully compatible version of Sun's Java compiler on Windows programs but in fact introduced an incompatible version which forced software writers to develop distinct Microsoft-compatible versions.

From a position of slight market share inferiority relative to Navigator in 1997, Microsoft's Internet Explorer surged ahead of Navigator in 1998 when Microsoft launched new Windows versions with the Internet Explorer fully bundled into and undetachable from the Windows operating system. If the operating system already included a wellfunctioning Microsoft browser, why bother separately installing Navigator? Microsoft also brought pressure to bear upon personal computer system assemblers and Internet service providers to emphasize Internet Explorer at the expense of Navigator. 
The U.S. Department of Justice Antitrust Division reacted to Microsoft's bundling decision with a narrowly-targeted complaint. ${ }^{2}$ When district court judge Thomas $P$. Jackson's December 1997 order to unbundle Internet Explorer was reversed by an appellate court, the Department of Justice escalated its attack, filing a broad complaint accusing Microsoft of monopolization, attempted monopolization, and illegal tying (i.e., bundling) and citing a wide array of practices used by Microsoft to thwart competition from rival operating systems and browsers. After an accelerated trial attempting to avoid the manifold delays plaguing the earlier U.S. antitrust case against IBM, Judge Jackson ruled in November 1999 that Microsoft had violated the Sherman Antitrust Act on numerous grounds. ${ }^{3}$ Judge Jackson then commissioned appellate court judge Richard Posner to mediate a settlement. When the settlement talks failed -- largely on Microsoft's unwillingness to make its computer codes more widely available -- Judge Jackson ordered in June of 2000 that Microsoft be broken into two parts, an operating systems company and an applications company, and required that it cease a variety of other restrictive practices.

Microsoft of course appealed to higher authority, and from that point on, the government's challenge faltered. In late 2000, George W. Bush prevailed over Al Gore in a contest for the U.S. presidency, thanks in part to a U.S. Supreme Court decision overturning a State of Florida supreme court decision accepting challenged ballots that gave Gore a narrow victory, both in Florida and the nation as a whole. Microsoft's appeal was heard by the District of Columbia appellate court. The choice of attorneys to plead the Department of Justice side was as always delicate. Normally such appeals are argued by staff of the Solicitor General, but on complex cases, it is not unusual for the appeal to be argued by the principal Antitrust Division attorney. Quite atypically, the Microsoft prosecution had been

2 . An earlier antitrust suit challenged Microsoft's policy of requiring computer assemblers to pay Microsoft a fee for each operating system they installed, whether it was Windows or that of a rival. A settlement was negotiated in July 1994. When District Court Judge Stanley Sporkin attempted to broaden the terms, he was reversed and removed from the case by an appellate court. See U.S. V. Microsoft Corp., 56 F. 2d 1448 (1995). Sporkin's ill-fated attempt to broaden the remedy was in part informed by the excellent Wallace and Erickson (1992) book.

3 . U.S. V. Microsoft Corporation, 84 F.Supp. 2d 9 (1999). For blow-by-blow accounts of the Justice Department suit and its forerunners, see Auletta (2001) and Heilemann (2001). I participated in the early Justice Department deliberations and prepared as a consultant for Sun Microsystems a detailed chronology of Microsoft's strategic actions. 
led for the Department of Justice by a prominent private sector trial attorney, David Boies. But Boies was also principal attorney for Al Gore in his appeal of the Florida presidential election outcome before both the Florida and U.S. supreme courts. Would a new Republican Department of Justice, led by an attorney general to whose failed senatorial election campaign Microsoft had contributed \$19,500, choose Boies to argue the appeal? Not surprisingly, the choice went to the Solicitor General staff. The author listened to the proceedings on the radio and concluded, as did Business Week the following week, ${ }^{4}$ that attorneys for the government simply did not understand the complex economics of the case. The appellate court ruled that Microsoft had in fact monopolized the PC operating system market and thereby violated the Sherman Act, but overturned several other counts of Judge Jackson's decision, including his finding that Microsoft's bundling was a per se Sherman Act violation. He invited the government to readdress the question of whether the bundling constituted a rule of reason violation. ${ }^{5}$

The Department of Justice chose not to pursue the appellate court's invitation on bundling, but instead negotiated with Microsoft what was generally considered a mild set of behavioral remedies, notably, avoidance of secret discounts to Windows licensors and disclosure of information sufficient to allow interoperability between Windows and writers of "middleware" software, i.e., browsers, Java translators, and e-mail programs. Dispute continued for several years over details of the disclosure obligations and the charges Microsoft was allowed to levy on those who received interoperability information. Eventually, the royalty rates demanded by Microsoft were substantially reduced as a result of Antitrust Division objections.

\section{The European Commission Case}

Despite being put on notice in 1997 that it risked antitrust challenges through strategic bundling, Microsoft in May 1999 physically bundled its Windows Media Player, cloned from a predecessor offered by Real Networks and previously provided as a separate software package, into its Windows operating systems. Having branched into the provision of computer server operating systems along with PC operating systems, Microsoft

\footnotetext{
4 . "Upfront: Did Microsoft Catch a Break?" Business Week, March 12, 2001, p. 14.

5 . U.S. v. Microsoft Corporation, 253 F. 3rd 34 (2001). In fact, Judge Jackson's decision included careful support for a rule of reason violation. The appellate court also Jackson for talking about the ongoing case with a reporter and for failing to hold hearings on the Justice Department's proposed remedial measures. But see the lengthy amici curiae brief by Litan, Noll, Nordhaus, and Scherer (2000).
} 
advertised that its servers interoperated more seamlessly with the ubiquitous Windows desktop operating systems than those of rival work group server software developers because of Microsoft's superior knowledge of the required intercommunication protocols.

The latter problem was apparently the initial impetus for a European Commission investigation, following a complaint from server provider Sun Microsystems. The investigation was broadened in February 2000 to include Microsoft's physical bundling of the Windows Media player, apparently on the basis of complaints inter alia from Microsoft rival Real Networks. On August 1, 2000, an initial statement of objections focusing on the interface disclosure problem was issued; it was amended to include the bundling issue on August 30, 2001. Following further proceedings, the Commission adopted in April 2004 a lengthy, carefully-argued decision concluding that Microsoft had violated the European Community law against abuse of a dominant position through its media player bundling and its biased disclosure of server interoperability data. ${ }^{6}$ Microsoft was fined 497 million Euros, ordered to offer a version of Windows with the Media Player unbundled, and required to provide information sufficient to allow other firms' server software to interoperate seamlessly with Windows desktop operating systems. Microsoft appealed to the European Court of First Instance for a stay of the remedies, but following a two-day hearing in Luxembourg, its appeal was rejected, ${ }^{7}$ and in September 2007 the Court of First Instance the Commission's 2004 decision was broadly upheld. ${ }^{8}$

Following the rejection of its petition for a stay of execution on remedies, Microsoft did offer a version of Windows with the Windows Media Player unbundled from the operating system. The measure was an abject failure, however, because the Commission allowed Microsoft to sell the unbundled system at the same price as the bundled system, and in the first nine months of availability, only one buyer out of every 20,000 chose the unbundled version. ${ }^{9}$ The Commission took a much tougher stance on the disclosure of

6 . Commission of the European Communities, Decision, Case COMP/C-3/37.792 (April 21, 2004).

7 . Order of the President of the Court of First Instance, December 22, 2004. I appeared before the Court as a witness on behalf of Real Networks. Sun Microsystems was originally scheduled as a complainant but settled its own private treble damages suit against Microsoft in the United States for \$1.9 billion and withdrew from the European proceedings.

8 . Microsoft Corp. V. Commission, Case T-201/04, September $17,2007$.

9 . "Microsoft in European Court Says 2004 Ruling Is a Failure," New York Times, December 23, 2005, p. C-16. 
interoperability information. Technical experts reported repeatedly that the information supplied by Microsoft was insufficient for smooth interoperability, and in 2006, the Commission began levying noncompliance fines eventually cumulating to 1.18 billion Euros before Microsoft's disclosures were judged adequate. Although it deferred to Microsoft on the pricing of an unbundled Windows Media Player, it rejected Microsoft's demands for a 5.95 percent royalty on software benefitting from its information disclosures and eventually imposed a maximum royalty rate of 0.4 percent.

In May of 2008 at a conference in St. Gallen, Switzerland, Judge Bo Vesterdorf, retired chief judge of the European Court of First Instance and presiding judge at the Microsoft appeal, expressed surprise at the magnitude of the non-compliance fines levied on Microsoft and warned that "one should be careful" not to encroach too much on patent rights "by a too-zealous enforcement of competition law." He warned further that such encroachment could "create legal uncertainty for the holders of intellectual property rights, thereby perhaps diminishing the incentives to sometimes desirable but very expensive research and development." 10 His concern presumably turned on both the compulsory licensing of Microsoft's patents and Commission intervention in requiring royalty rates much lower than those sought by Microsoft.

Although Judge Vesterdorf's fears were in theory warranted, they (and the records supporting both the U.S. and European Microsoft proceedings) ignored important truths. First, the compulsory licensing of key patents had been ordered in settlement of more than 100 U.S. antitrust cases. Despite complaints that such compulsory licensing threatened investments in innovation, careful investigations revealed that at least among wellestablished corporations, the compulsory licensing decrees had little or no discernible adverse effect on the subject companies' R\&D investments. ${ }^{11}$ Second, although Microsoft invested prodigiously in research and development and the provision of erratically reliable software packages, its record as a true innovator left much to be desired. See Table 1. Most of its "innovations," it seems clear, were cribbed and then expanded upon from the efforts of others. Requiring it to license information needed to make its software function seamlessly with others' offerings hardly seems likely to dampen the vigorous pace of innovation that has characterized the computer software industries.

\section{Intel}

The integrated circuit, emerging in the late 1950s, was without doubt one of the

10 . From a Reuters news dispatch May 22, 2008, by David Lawsky, read on the American Antitrust Institute web site.

11 . See Scherer (1977), pp. 59-78; and Scherer (2008), especially the discussion of Xerox at pp. 1054-1057. 
greatest inventions made during the 20th Century. ${ }^{12}$ That step alone, however, would have been relatively unimportant had it not been for incessant production process improvements making possible astonishing increases in integrated circuit density and speed characterized by "Moore's Law," first articulated by Gordon Moore, a founder of the Intel Corporation. ${ }^{13}$ Also crucial to the emergence of powerful high-speed computers, including personal computers, was the microprocessor, often called in its early years the "computer on a chip." Credit for the 1971 invention generally goes to Ted Hoff of the Intel Corporation, although Hoff himself has said that the advancing state of the art made the invention virtually inevitable, and if he had not taken the honors, "somebody else would have."14

Rapid improvements in the power and speed of microprocessors and complementary dynamic random access memory chips (DRAMs) set the stage for the advent of personal computers in the late 1970s. A key event, as observed earlier, was the introduction of the IBM Personal Computer in August 1981. IBM chose among three contenders the Intel 8086 microprocessor to run its Microsoft MS/DOS operating system. With this choice, a software compatibility bandwagon effect made Intel, like Microsoft, the greatly preferred basis for personal computer operation. After first using Motorola and then IBM microprocessors, Apple eventually also switched to the Intel architecture for its Macintosh personal computers. In choosing Intel as its microprocessor supplier, however, IBM was wary of becoming locked into a single source. It therefore demanded as a condition for buying Intel's microprocessors that Intel establish a fully competitive second source. Advanced Micro Devices (AMD), which at the time produced specialized processors, was chosen as the second source, and in its contract with Intel AMD was given full access to Intel's intellectual property, its circuit architecture, and (crucially) the information needed to produce new versions of the Intel processor. Its competitive efforts succeeded beyond Intel's expectations, so that by the mid 1980s it had gained nearly half of so-called "I-86" microprocessor orders. The royalty scheme worked out between the two firms turned out to be disadvantageous to Intel, since it was based upon the companies' proprietary chip complexity rather than volume, and the Intel chips turned out unexpectedly to sell in much larger quantities than AMD's specialized offerings.

12 . On the early history, see Scherer (1996, pp. 202-204).

13 . See Flamm (1993, 2007). Moore predicted in 1965 that integrated circuit density would double annually -- a figure he later revised to every 18 months.

14 . "Modern Wonders: The Age of the Thing," The Economist, December 25, 1993, p. 47. 
Intel was not pleased. ${ }^{15}$ The first versions of the Intel chips chosen by IBM processed data in 16-bit chunks. Intel's management decided to move up to 32-bit microprocessors and made a conscious decision not to notify AMD, as it was contractually obliged to do, of its plans. The first Intel 32-bit processor, the I-80386, was rolled out commercially in September 1986. When AMD finally learned of Intel's plans, it was well behind any schedule it could have achieved even if Intel provided the necessary architectural information. And Intel refused to provide any design information, requiring AMD to begin ab initio in developing its own Intel-compatible chip. Meanwhile, it invoked the arbitration clause in its contract with Intel, eventually winning on most counts, including rights to imitate the Intel architecture. ${ }^{16}$ AMD introduced its first 32-bit clone, the AMD-386, only in 1991. It was joined as a competitor in 1992 by another firm, Cyrix, which also launched challenges against Intel under the U.S. antitrust laws, ${ }^{17}$ but failed to sustain market momentum and eventually was taken over by a Taiwanese company, Via.

After AMD and Cyrix entered the market with I-86 compatible microprocessors, Intel pursued a variety of strategies to counter them. The pace of Intel's chip innovation accelerated significantly after inter-chip rivalry began, as Figure 3 reveals. ${ }^{18} \mathrm{Up}$ to about 2005 , the main focus of rivalry among microprocessor vendors was chip speed, measured in millions of clock cycles (megahertz) per second, and with three firms competing to offer Intel architecture, Intel was forced to accelerate the rate at which it introduced faster chips.

Along with innovating more rapidly, Intel pursued several other strategies to thwart

15 . This paragraph is based upon the author's personal knowledge gained as a consultant to AMD in AMD's arbitration and competition policy disputes with Intel during the 1990s.

16 . See "Competitor Wins Right from Intel," New York Times, February 25, 1992, p. C1; and (on judicial affirmation) "State Court Ruling Protects AMD Rights To Clone, Sell older Line of Intel Chips," Wall Street Journal, January 3, 1995.

17 . See Wilson and Warren-Boulton (1995).

18 The diagram was prepared but not used in connection with the author's work as principal economic consultant for a Federal Trade Commission case narrowly focused on Intel's data disclosure practices with respect to chip buyers who challenged its patents. The case was settled before trial in 1999. In the matter of Intel Corporation, FTC docket 9288, Consent Order (1999). The diagram was included in the author's testimony before the Court of First Instance in the Microsoft case.

AMD's first 32-bit microprocessor was the AMD-386. The AMD-486 was a similar microprocessor coupled with a math co-processor, which previously had been sold separately. 
its rivals. It intoduced "fighting brands" such as the Celeron -- i.e., chips based upon prior designs, but with some functionality impaired so they could be sold at lower prices. It brought patent infringement suits in situations where rival rights were unclear. In the early stages of a new chip's life cycle, quantities were limited, and computer assemblers who were loyal to Intel were given first access to chip supplies, disadvantaging computer makers who split their business between Intel and rivals. Similar disparities were sustained on access to advance information about microprocessor interfaces, needed to design new computer models. Under its "Intel Inside" program, it granted computer makers advertising discounts, conditional upon displaying the popular "Intel Inside" logo only on computer lines using Intel chips exclusively. Other discounts were structured to reward loyalty to Intel.

To understand Intel's discount strategy, which was the central focus of the European Commission's case against Intel, one must delve more deeply into the economics of semiconductor production -- a digression that, alas, was not taken in the European Commission's otherwise admirable Intel case decision.

Semiconductors represent the classic learning curve industry. ${ }^{19}$ At least in the early stages of production, one learns "by doing" how to avoid defective chips and increase volume as additional chips are produced. Typically, each doubling and redoubling of cumulative chip volume reduces unit batch costs by 20 to 30 percent. Learning curves tend to be linear on doubly logarithmic coordinates, and their "slope" is stated to be 100 minus the percentage by which costs are reduced with each doubling of cumulative output. This leads causes among other things to a phenomenon often ignored in the economics literature: because each batch causes learning that reduces future batch costs, marginal costs, taking into account both current costs and the impact on future costs, are far below current batch costs -- more so when the future cost impact is not discounted to present value, as compared to when the impact of learning on future costs is discounted. Figure 4 provides a fairly typical example, using DRAM volumes experienced during the late 1980 s. $^{20}$ At cumulative production of 100,000 chips, for instance, batch costs are $\$ 6.75$ while discounted marginal costs are only $\$ 3.03$. According to information compiled by the author during the 1990s, the curves bottom out somewhere between cumulative "good" chip volumes of 5 and 50 million. Learning curve data are extremely confidential, so it is unclear whether these relationships persist into the 21 st century. The existence of a substantial discrepancy between average batch and marginal costs and the advantages of

19 . See Scherer (1996, Chapter 6); and Flamm (1993), chapters 6 and 7 . For a basic theoretical contribution, see Spence (1981).

20 . It is drawn from scherer (1996), p. 211, using sales timing information published in Flaherty (1992). 
augmenting current volume for future cost efficiency give rise among other things to tendencies for very aggressive pricing in the early stages of learning. ${ }^{21}$ That these dynamics continue into the 21st century is suggested by the aggressive pricing that emerged during the so-called "dot.com" recession of 2000-2001, motivating price fixing agreements that led to U.S. and European antitrust interventions against DRAM (and also flash memory) producers. ${ }^{22}$

There is more. Figure 4 focuses only on what might be called variable batch costs. In addition, huge front-end costs are incurred to devise and lay out new circuit architecture, test it, and prepare the tooling required to produce a new generation of circuits. Ignoring the billions of dollars spent to build and equip a fabricating facility (a "fab"), it has been estimated that the front-end sunk costs incurred for a new generation of microprocessors amount to hundreds of millions of dollars. ${ }^{23}$ Figure 5 combines average variable batch cost curves, assuming a relatively conservative 80 percent learning curve slope and falling (since microprocessors are more complex and costly than DRAMs) to \$50 per chip (dot-dot-dash line), with an average fixed cost curve (dotted line), assuming setup costs for a new line to be $\$ 300$ million. Average total cost (solid line) is found to fall all the way out to a cumulative volume of at least 20 million chips, showing what is in effect a natural monopoly condition. And even at very high volumes, batch costs are substantially below average total costs. These are conditions under which, if there are several rivals rather than a single natural monopolist, aggressive price wars can be expected, absent strong oligopolistic coordination. ${ }^{24}$

The natural monopoly state of microprocessor production, at least at volumes up to 20 million chips, argues for concentrating production in a single firm. But the technological rivalry effect shown by Figure 3 argues for competition, at least among two or a handful of firms. A difficult tradeoff is required. The author's own judgment is that, at least for higher-volume chips, more rapid innovation should trump natural monopoly cost considerations, but on this, reasonable observers could disagree. No such tradeoff was

21 . See Scherer (1996, pp. 212-214).

22 . See (on the U.S. case) "Samsung To Pay Large Fine in Price-Fixing Conspiracy," New York Times, October 14, 2003; and (on the European case) "An Old Chip Cartel Case Is Brought to a Swift End," New York Times, May 20, 2010. Fines of 331 million Euros were levied in the latter case.

23 U.S. Federal Trade Commission, Complaint, In the Matter of Intel, December 16, 2009, para. 43.

24 . See for historical comparison Jones (1920). See also Scherer and Ross (1990), pp. 294-308. 
attempted in the European Commission case with respect to Intel, which will be described more fully in what follows.

Figure 6 abstracts from front-end fixed costs to consider the kind of pricing that might be expected in microprocessors with one and then two firms and learning-by-doing that persists out to 10 million chips produced. It assumes that Intel leads the way into a new generation of microprocessors and advances rapidly down its 80 percent learning curve before AMD responds with its own version. With a much smaller market share, AMD advances only slowly down the batch cost learning curve, with progress denoted by quarter-year marks (e.g., Q1, Q2, etc.). Without competition, Intel pursues a typical monopoly pricing strategy -- below cost initially to stimulate demand and then increasingly above cost. 25 However, when AMD progresses at quarter 2 far enough to have costs below Intel's monopoly price, Intel initiates what its staff during the late 1990s called "the waterfall," reducing its price in one step along AB to a level below AMD's costs and holding it there until AMD has produced a cumulative total of a million good chips. In this way, profitable competition by AMD was rendered difficult even if not impossible.

There was a possible escape hatch for AMD -- accelerated innovation, with which AMD minimized its technological lag vis a vis Intel or even took the lead. At first, as AMD struggled to catch up, this was difficult. AMD's first early technological lead came soon after its move into 32-bit processors when it introduced chips that consumed less power than Intel counterparts. These were particularly advantageous for use in battery-powered laptop computers and were therefore widely successful in Taiwan, where most of the world's laptops were produced. Intel's response was a patent infringement suit against AMD's Taiwanese customers, which was eventually thwarted through an antitrust investigation by the Taiwan Fair Trade Commission. ${ }^{26}$ AMD subsequently moved ahead of Intel with faster chips, 64-bit Intel-compatible chips, and multiple core chips (generating less heat relative to processing power).

With AMD emerging as a more potent even if limited-line rival, Intel needed new strategies. One that it adopted was to offer computer assemblers (and in some cases computer retailing chains) rebates conditional on allocating the lion's share of their microprocessor purchases to Intel. Actual data are not available because the European Commission chose not to disclose them. But consider the following simplified but plausible illustration. Suppose the total demand for a microprocessor design is 1,000 units at a price of $\$ 100$. Total sales revenue will be $\$ 100,000$. If Intel normally takes 90 percent of the business, its sales will be $\$ 90,000$ and AMD's sales will be $\$ 10,000$. Suppose now that Intel

25 . See Flamm (1993), Chapter 6.

26 . In March 1994 the author testified on behalf of AMD before the Taiwan Fair Trade Commission. 
offers its customers first-dollar rebates conditional upon their purchasing at least 90 percent of their chips from it. If all purchasers meet the quota, they receive a discount of 10 percent, or 10 percent times $\$ 90,000=\$ 9,000$. For AMD to match this rebate in absolute volume, it would have to refund $\$ 9,000$, or almost all of its sales if it gains only 10 percent of the market but a smaller percentage of its sales if by matching the rebate it can win a share of the market greater than 10 percent -- e.g., 45 percent of its sales if it can increase its market share to 20 percent while maintaining a list price of $\$ 100 .{ }^{27}$ Needless to say, this is a difficult challenge for AMD to meet. ${ }^{28}$

\section{The European Commission Case}

It was this conditional rebate scheme that drew a challenge from the European Commission, prompted by complaints to the Commission by AMD in October of 2000 and November 2003 and to the German Competition Authority in July 2006. The Commission launched investigations in two main stages, focusing first on Intel's discounts to computer assemblers and then on its discounts to a German retailer, Media-Saturn-Holding GMBH. On May 13, 2009, the Commission held that Intel had violated Article 92 of the European Community Treaty by virtue of its volume-dependent rebates. ${ }^{29}$ It levied a fine of 1.06 billion Euros -- the largest fine imposed on a single company in EC history. Although the fine was large in absolute amount, it was roughly equivalent to six weeks of Intel sales, said by the Commission to be approximately 30 percent of total company annual sales. Intel was also ordered to refrain from any "act or conduct having the same or equivalent object or effect" -- i.e., to cease granting exclusionary volume-linked rebates.

Intel was said to control in the ten-year period 1997-2007 approximately 70 percent of what the Commission said was the relevant market -- defined as the worldwide market for micro-processors based upon Intel I-86 architecture. Ignored therefore were sales of specialized microprocessors used mainly in servers, specialized graphical data processors, and the very large set of special-purpose microprocessors for such applications as cell phone operation and automobile engine and industrial machine control. This is no doubt a defensible backward-looking market definition, but it is likely to become increasingly questionable in the future as late-generation multi-function smartphones and

27 . In fact, the evidence suggests that AMD had to sell its chips at lower list prices than Intel's.

28 . See for example "Dell in Talks To Settle Itel Inquiry With S.E.C.," New York Times, June 11, 2010, p. B1, in which Intel's CEO refers to Dell as "the best friend money can buy."

29 . Commission Decision, Case COMP/C-3-37990-Intel (May 13, 2009), provisional non-confidential version, accessible (like other Commission decisions) on the World Wide Web. 
computers such as the Apple iPad, introduced in 2010, compete with traditional computing devices.

The Commission's decision was consistent with the dim view it had taken in prior cases of volume-linked rebates and discounts that encourage recipients to deal exclusively or nearly exclusively with dominant firms. It recognized the important role played by innovation in focusing consumer demand and acknowledged AMD's recent leaps ahead of Intel in clock speed, 64-bit I-86 architecture, ${ }^{30}$ and multi-core processors.

The Commission pioneered methodologically in the use of what it called an "efficient competitor analysis." The issue was how volume-related rebates by a dominant firm affected the price-cost competitiveness of smaller rivals forced to match the rebates to retain or gain sales. The question was, does the absolute rebate, spread over the "contestable" sales the smaller rival could reasonably expect to achieve, bring the net perunit price realized by the smaller rival below the smalller rival's "average avoidable cost?" If so, the Commission reasoned, the rebates could render the smaller rival unprofitable at the margin and therefore jeopardize its longer-run viability. This approach is a detailed variant of the "average variable cost" test for predation proposed by Areeda and Turner (1975). ${ }^{31}$ Although the decision is not completely clear because of numerous data excisions, the Commission apparently estimated the costs of an "efficient competitor" by focusing on the average variable cost of Intel itself. This approach, as the Commission recognized in para. 1037 of its decision, is conservative and "more favourable to Intel," since AMD's costs were presumably higher than those of Intel because, at least in the early stages of production, it operated farther up its learning curve than its larger rival -- a phenomenon acknowledged only obliquely by the Commission. If volume-linked rebates brought net prices for the rival below the variable costs of Intel, they almost surely had an even greater deterrent impact on smaller AMD. The Commission admitted considerable difficulty obtaining reliable data on "average avoidable cost." The only estimate made public (para. 1043) by the Commission was derived from Intel's aggregate public financial

30 . However, it failed to describe Intel's earlier mistake, developing at huge cost a 64-bit chip, the Itanium, incompatible with prior Intel architecture.

31 . The Areeda-Turner rule was argued to be analytically deficient by several economists, including a recent Nobel prize laureate. For a review of the debate, see scherer and Ross (1990), pp. 468-479. The diligent reader is cautioned that Figures 12.2(a) and (b) were transposed. In Matsushita Electric Industrial Corp. v. Zenith Radio, 475 U.S. 574, at pp. 584-5, the U.S. Supreme court observed that "there is a good deal of debate on what cost is relevant in [alleged predation] cases" but chose not to resolve the debate. 
statements, showing that its "cost of goods sold" was 35 percent of its average selling price. The decision apparently relied significantly upon that figure, given conflicting estimates from expert witnesses.

\section{The U.S. Federal Trade Commission Case}

Issuance of a monopolization complaint by the U.S. Federal Trade Commission in December 2009, only seven months after the European Commission's Intel decision, might be viewed as an example of regulatory "piling on." 32 The complaint, which before a negotiated settlement was reached in August 2010,33 was scheduled to be tried on a "fast track" schedule allowing only 161 courtroom hours for each side to present its case, is distinguishable from the European Commission action on several counts.

First, the Intel conduct at issue was specified to commence beginning only in 1999. This exclusion, not explained in the Commission's complaint, was presumably dictated by the fact that the Federal Trade Commission concluded in 1999 through consent settlement a previous case against Intel focusing mainly on Intel's actions taken toward customers who sued it for patent infringement.

Second, the relevant (worldwide) product markets proposed by the FTC were broader than those of the EC: they spanned both central processing units (CPUs, i.e., microprocessors) for personal computers and servers (but excluded cell phone processors); plus graphics processor units (GPUs), which, the Commission asserted, "are adding more CPU functionality with each product generation" and hence "are a threat to Intel's monopoly in the relevant CPU market" (para. 15). ${ }^{34}$ Intel was said to hold market shares of 75 to 85 percent in the alleged CPU markets and "in excess of 50 percent" in the GPU markets.

Third, the FTC complaint encompassed a much wider array of conduct than the

32

In the Matter of Intel Corporation, Docket No. 9341 (December 16, 2009). Only a month earlier, AMD settled its own private antitrust suit against Intel by accepting $\$ 1.25$ million in alleged damages (which made up nearly all of AMD's reported 2009 profits). In November 2009, the State of New York also launched an antitrust suit against Intel -- presumably stimulated by the ongoing construction of a large AMD-linked plant un upper New York state.

33 In the Matter of Intel Corporation, Docket No. 9341, Decision and Order, August 4, 2010.

34 . See also "New Nvidia Chip Steps Closer to Superconducting in the PC," New York Times, Nov. 9, 2006. 
European Commission case. It challenged volume-dependent rebates, as did the EC case. However, it also reached inter alia discounts granted by Intel to computer assemblers for delaying the launch of rival products, preferred access to chips during periods of shortage, variation in marketing support to reward more faithful customers, the manipulation of software and interfaces to degrade the performance of rival processors, misrepresentation of performance benchmark reports on competitor as compared to Intel products, discriminatory access to Intel intellectual property, and through both design changes and information suppression, impeding the interoperability of rival GPU chips with Intel microprocessors.

Fourth, the FTC proposed to prohibit all the conduct of which it complained. This seems an eminently logical step. In practice, however, it faces formidable difficulties. When conduct is prohibited, the prohibitor bears the burden of monitoring the respondent's actions in subsequent years to ensure that it does not recur. The varieties of conduct singled out by the FTC as contrary to law were so vast and so complex, and the remedy negotiated in August 2010 was so correspndingly far-reaching that, for effective monitoring, a substantial and technically proficient compliance staff would be required into the future (with a six year horizon set in the negotiated settlement). The great difficulties the U.S. Department of Justice and the European Commission competition authorities experienced monitoring Microsoft's compliance with relatively narrow information disclosure mandates suggest even greater problems in monitoring a much broader array of Intel conduct. From my own experience as head of the FTC's Bureau of Economics during the 1970s, I know that the FTC did not possess such monitoring capability then. The Commission apparently recognized its inability to do the monitoring job on its own. The negotiated settlement requires Intel to pay up to $\$ 2$ million to compensate technical consultants hired by the Federal Trade Commission for purposes of monitoring and judging inevitable conflicts as to whether e.g. disclosure of interfaces has been sufficient and whether changes in Intel designs degrade the functioning of complementary chips. Whether this will be sufficient remains to be seen. Doubts intrude when one recognizes that, at a $\$ 500$ per hour fee typical for experts at the time, expert advisor time of only about 17 normal working weeks per year over six years would be compensated under the arrangement. The tasks may prove to be more difficult than provisions for their support assume.

It has long been a philosophical maxim in competition policy circles that proven abuses of monopoly power can be combatted in either of two ways: through conduct remedies that channel a dominant firm's actions into desired patterns, or through structural remedies that render industry structure more competitive and hence more likely to function workably, guided by the "invisible hand." 35 Structural remedies are to conduct

35 The belief is so deeply and long-ingrained that I am no
longer able to provide citations to definitive literature 
remedies as surgery is to sustained pharmaceutical therapy. With surgery, there is pain in the short run, after which, one hopes, the patient will live healthily ever after.

Pharmaceutical therapy on the other hand requires continuing application and monitoring to ensure that dosages are correct and resistance has not emerged. In the FTC's Intel complaint, one sees no evidence that the structural alternative was considered. ${ }^{36}$

The agreed-upon Intel conduct remedies may be the most complex ever attempted in U.S. antitrust history. Monitoring conduct in detail is highly regulatory. One must be apprehensive, however, about imposing the pain of alternative structural remedies upon a company that has performed as efficiently and innovatively as Intel. ${ }^{37}$ In terms of plant structure, Intel does not pose the single-unit difficulties that deterred Judge Wyzanski from fragmenting the United Shoe Machinery Corporation in $1953^{38}$ and complicated possible structural reorganization of Microsoft (with most of its software-writing operations concentrated at the time in a single Redmond, Washington, campus). ${ }^{39}$ As of the late 1990s, Intel had 61 production facilities in the United States and 25 overseas. And it had at least three well-staffed chip development groups -- one in Silicon Valley, one in Oregon, and one in Israel. Splitting Intel into three viable units would almost surely have been feasible. However, I have emphasized earlier the natural monopoly character of microprocessor development and production, at least at the individual chip generation level even if not at

sources. For an anticipation, see Kaysen and Turner (1959), especially p. 96.

It should be noted that structural remedies include not only breakup of a single firm into multiple entities, but also such actions as merger controls and the compulsory licensing of patents or other intellectual property undergirding monopoly positions. Intel already had patent licensing agreements with its three main competitors, but the Commission's final order recognizes that changes in the future could impair their effectiveness,

36 . For an explicit attempt to weigh structural vs. conduct remedies in the U.S. Microsoft case, see Litan et al. (2000).

37 . However, Intel has been remarkably dependent upon other organizations' basic architectural concept innovations. See Flamm (2007), Figure 12.

38 . U.S. v. United Shoe Machinery Corp., 110 F. Supp. 295 (1953), affirmed at 347 U.S. 521 (1954). On the subsequent difficulties, see Scherer (2008), p. 1050, note 67.

39 . See again Litan et al. (2000). 
the level of a multi-design, multi-plant production operation. Scale economies might be lost, and with a more fragmented industry structure whose marginal costs are low relative to average total costs, there is a danger of cut-throat price competition during recessions. The remedy decision was very difficult, with arguments on one hand as compelling facially as those on the other hand. It cannot be said confidently that the Federal Trade Commission erred in its choice of a highly regulatory approach, despite its inconsistency with the general trend of U.S. government - industry interactions during the past half century.

\section{Adjudication Problems}

When one compares the U.S. and E.C. approaches to the Microsoft and Intel challenges, one finds good reason to applaud the European Commission's performance. The European approach to dominant firm abuse problems has tended to be more tightly focused, targeting two main facets of Microsoft's practices and conditional discounts in two sectors of Intel's marketing, as compared to the broader array of practices addressed in the U.S. Microsoft and Intel cases. The E.C. of course took the lead in challenging Intel, although it lagged on Microsoft. And the E.C. was much tougher in following through on Microsoft, insisting that its disclosure mandates be satisfied. It is too early to assess the Federal Trade Commission's performance with respect to Intel.

Some aspects of the European Commission's performance, however, cry out for criticism. It is awkward for an American to advance the critique, but it must be done, and I have not seen it done by European economists.

We who have worked on competition policy in the United States have had drilled into our heads the mantra that the task of the government enforcement agencies is to protect the process of competition, not to protect competitors. Among other things, although we were not unwilling to entertain complaints and information from aggrieved competitors, we tried hard to treat such interventions skeptically, recognizing the mixed motives of the complainants, and marshall our own analysis and evidence presentation rather than relying on third-party expert witnesses. The European Commission openly admits in its decision documents that the Microsoft case was initiated following a complaint from Sun Microsystems and the Intel case following a complaint from AMD. At the Court of First Instance hearing on Microsoft in Luxembourg in October 2004, I appeared an a witness explicitly on behalf of Real Networks; engineers for Real Networks also testified; and there was additional testimony from representatives of other aggrieved software companies. The legal argumentation was to be sure carried by the Commission's attorneys, but there was no expert testimony from the Commission's economics staff. This, I believe, conveys the wrong image of what competition policy is, or at least should be, all about. The Commission should use its own staff as expert witnesses, not rely on those of aggrieved competitors. And when the necessary expertise is lacking internally, the Commission should do as the American antitrust agencies do, hiring outside experts, 
supporting their preparation, and presenting them as their own witnesses, not as representatives of third parties. ${ }^{40}$

Also, the adjudication process underlying a European Commission decision to issue statements of violation and remedy tends to be a star chamber proceeding, in which evidence is presented at a forum open to neither the public nor to counsel for accused parties. The parties affected are to be sure heard, but not in direct confrontation with opposing witnesses and counsel. In its May 13, 2009, decision, the Commission makes the remarkable admission (paras. 28-29) that Intel attorneys were given access to the complete case file, including confidential documents and testimony, on only three days -31 July 2007, 23 July 2008, and 19 December 2008. Presumably, Intel counsel were allowed to bring a copying machine with them, but on this, the record is silent. And disclosure of the information obtained beyond Intel's counsel and economic advisers was prohibited. Intel's February 2009 request for an oral hearing before Commission staff concerning the Commission's Supplementary Statement of Objections was denied. Technically, the Commission's proceedings did not anticipate criminal liability, and Intel arguably is not a human person, so the proceedings fall outside the scope of United Nations Universal Declaration of Human Rights (1948) Article 10, which states that:

Everyone is entitled in full equality to a fair and public hearing, in the determination of his rights and obligations and of any criminal charge against him.

Nevertheless, in view of the substantial penalties assessed, it would appear proper that a more even-handed and more open approach to adjudicating such major competition policy issues should be adopted. ${ }^{41}$

A complement to the closed form of Commission hearings is the failure to disclose in decision documents the identities of those who have testified as expert witnesses. The Commission's May 13, 2009, decision on Intel reveals that Intel presented reports from at least two economic experts, but the individuals are designated in the non-confidential version only as "Professor [...]" or in one instance as an unnamed Professor of Management in the Graduate School of Business at Stanford University (para. 1044). Open publication of

40 In the U.S. FTC's remedial approach to the Intel case, continuing intervention by Intel rivals seems inevitable if Intel deviations from the agreed-upon conduct rules are to be monitored.

41 . See also the "leader, "Prosecutor, Judge and Jury," The Economist, February 20, 2010, p. 15, asserting in the wake of the Intel case that "Enforcement of competition law in Europe is unjust and must change." See also concerning a new E.C. inquiry on Microsoft, "Microsoft Accuses Europe of Colluding with Rivals," New York Times, March 3, 2006, p. C2. 
one's views is a critical aspect of credibility for academics. Having one's views open to criticism by peers is an important incentive for doing the best job one can and constantly aspiring to the goal of Veritas. The European Commission would be well advised to reform its witness confrontation and disclosure standards to follow the maxim on the basis of which President Theodore Roosevelt created the predecessor to the U.S. Federal Trade Commission as a remedy for the perceived misdeeds of the so-called "trusts": 42

Publicity is the only sure remedy which we can now invoke... The first requisite is knowledge, full and complete -- knowledge which may be made public to the world.

42 . From Addresses and Presidential Messages of Theodore Roosevelt, 1902-1904, p. 294. 


\section{REFERENCES}

Phillip Areeda and Donald F. Turner, "Predatory Pricing and Related Practices under Section 2 of the Sherman Act," Harvard Law Review, vol. 88 (February 1975), pp. 697-733.

Ken Auletta, World War 3.0: Microsoft vs. the U.S. Government (Random House: 2001).

Marie Therese Flaherty, "Manufacturing and Firm Performance in TechnologyIntensive Industries: U.S. and Japanese DRAM Experience," Review of Industrial Organization, vol. 7 (1992), pp.

Kenneth Flamm, Mismanaged Trade? Strategic Policy and the Semiconductor Industry (Brookings Institution: 1993).

Kenneth Flamm, "The Microeconomics of Microprocessor Innovation," working paper, University of Texas at Austin (June 2007).

John Heilemann, Pride Before the Fall: The Trials of Bill Gates and the End of the Microsoft Era (HarperCollins 2001).

Eliot Jones, "Is Competition in Industry Ruinous," Quarterly Journal of Economics, vol. 34 (1920), pp. 473-519.

Michael Katz and Carl Shapiro, "Systems Competition and Network Effects," ournal of Economic Perspectives, vol. 8 (Spring 1994), pp. 93-115.

Carl Kaysen and Donald F. Turner, Antitrust Policy: An Economic and Legal Analysis (Harvard University Press: 1959).

Robert Litan, Roger Noll, William D. Nordhaus, and F. M. Scherer, Remedies Brief of Amici Curiae, in the matter of U.S. v. Microsoft Corporation (April 27, 2000).

Priscilla Offenhauer and F. M. Scherer, "Microsoft on Trial," John F. Kennedy School of Government case CR14-99-1522.0 (1999).

F. M. Scherer, The Economic Effects of Compulsory Patent Licensing (New York University Monograph Series in Finance and Economics 1977-2 (1977).

F. M. Scherer and David Ross, Industrial Market Structure and Economic Performance. Third ed. (Boston: Houghton-Mifflin, 1990).

F. M. Scherer, Industry Structure, Strategy, and Public Policy (HarperCollins: 1996). 
F. M. Scherer, "Innovation and Monopolization," in Issues in Competition Policy, vol. II (American Bar Association: 2008), Chapter 44.

A. Michael Spence, "The Learning Curve and Competition," Bell Journal of Economics, vol. 12 (Spring 1981), pp. 49-70.

James Wallace and Jim Ericson, Hard Drive: Bill Gates and the Making of the Microsoft Empire (Wiley: 1992).

Robert W. Wilson and Frederick Warren-Boulton, "Riding the Wave: Exclusionary Practices in Markets for Microprocessors," International Journal of the Economics of Business, vol. 2 (July 1995), pp. 241-262. 
Table 1

Precursors to Microsoft's Principal Software Innovations $\underline{\text { Microsoft Program }}$

$\underline{\text { Precursors }}$

BASIC for Altair "Computer"Dartmouth College Basic Program written by Kennedy and Kurtz

EXCEL Spreadsheet

VisiCalc (written by Harvard Business School student) and Lotus 1-2-3.

WORD word processor WordStar, WordPerfect

Power Point

Purchased from Sunnyvale, CA, startup firm's "Presentation" program.

Windows Adapted from Apple's Macintosh operating system.

Internet Explorer

Leased from Spyglass, cousin of Netscape's Navigator.

Windows Media Player

Adapted from Real Networks' Real Player 


\section{Figure 1}

Desktop Applications Use in the Mid-1990s

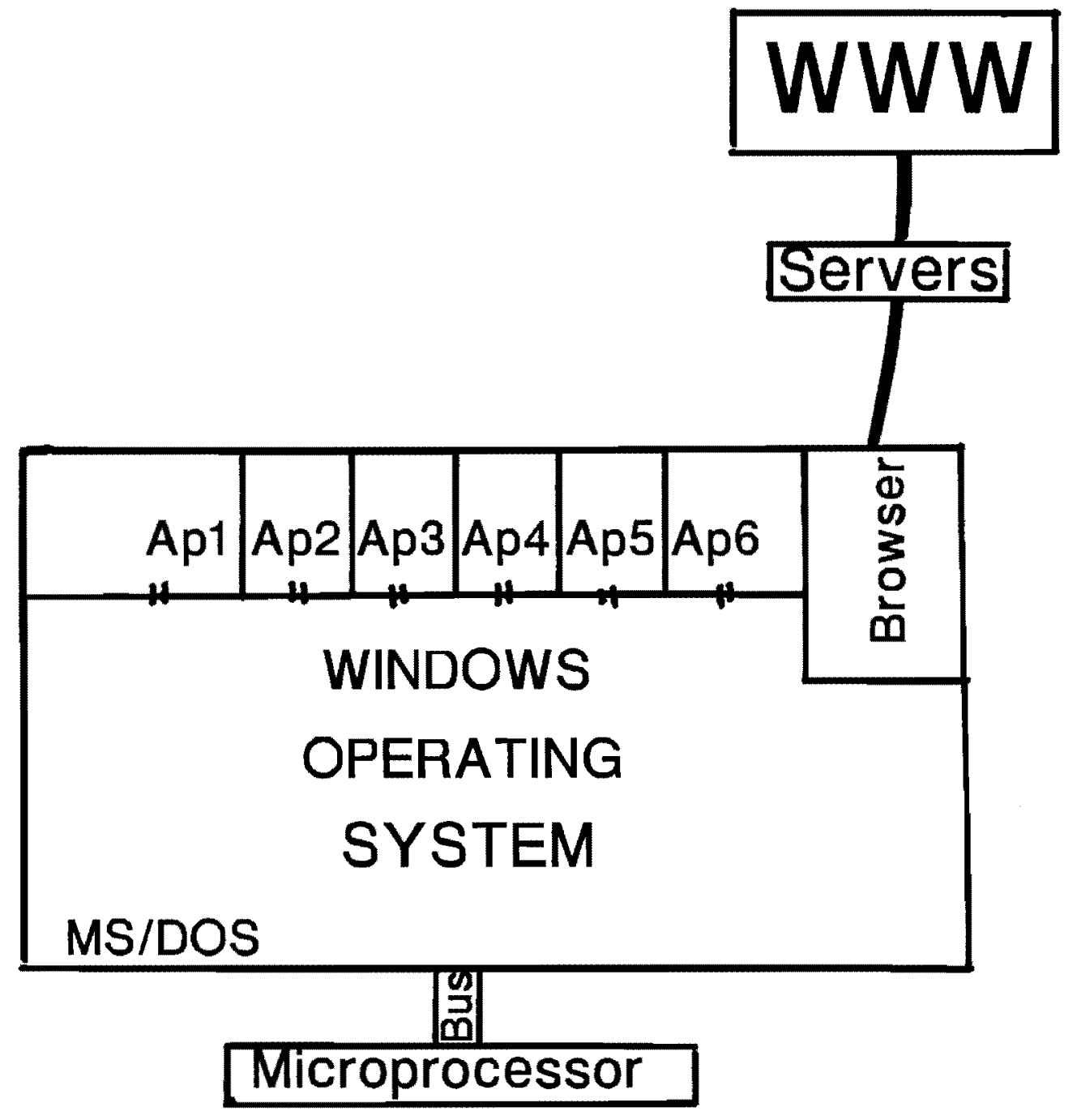


Figure 2

Microsoft's Nightmare Vision of Future Computing

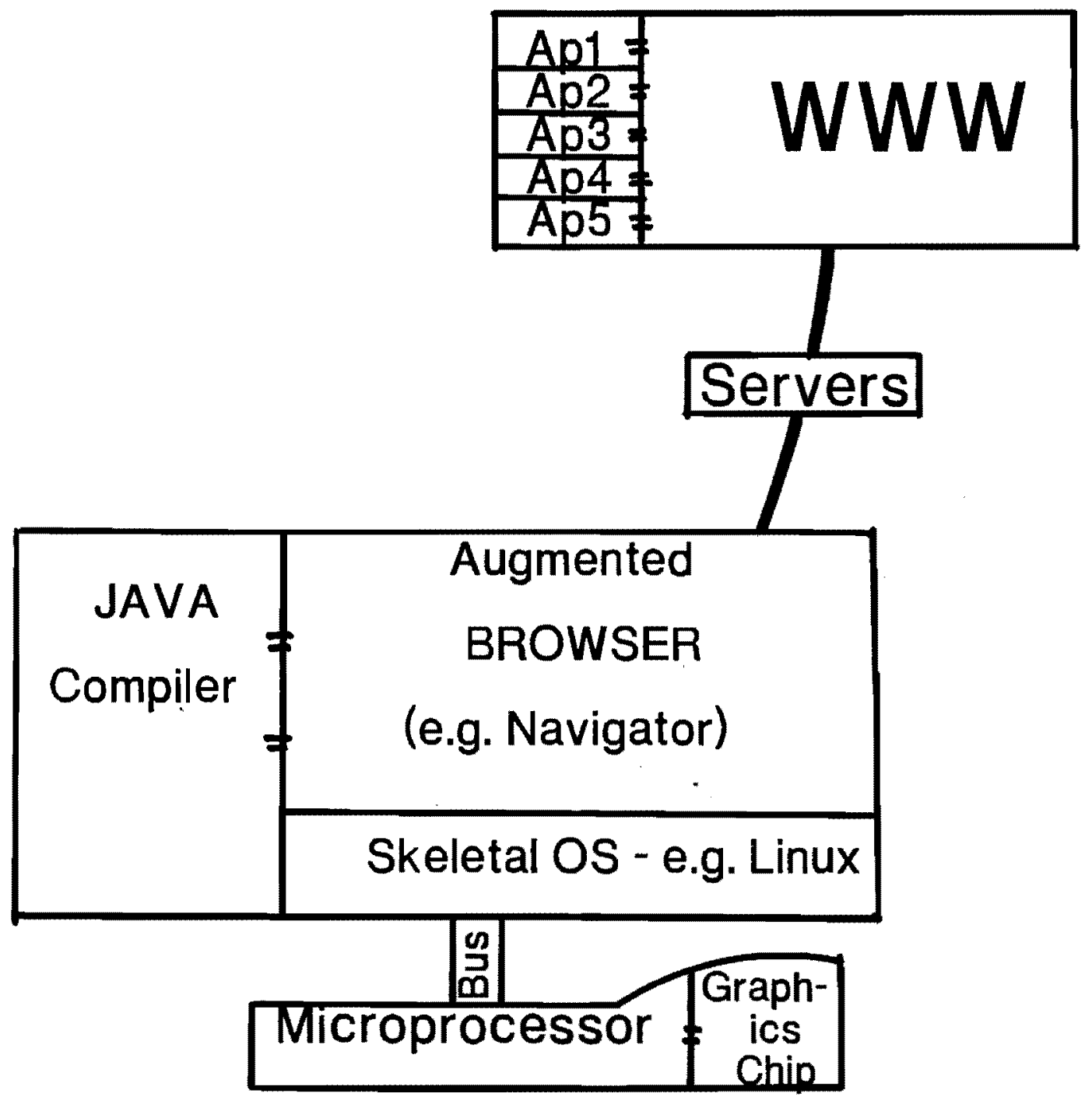


Figure 3

Time Trend of Intel Microprocessor Introductions

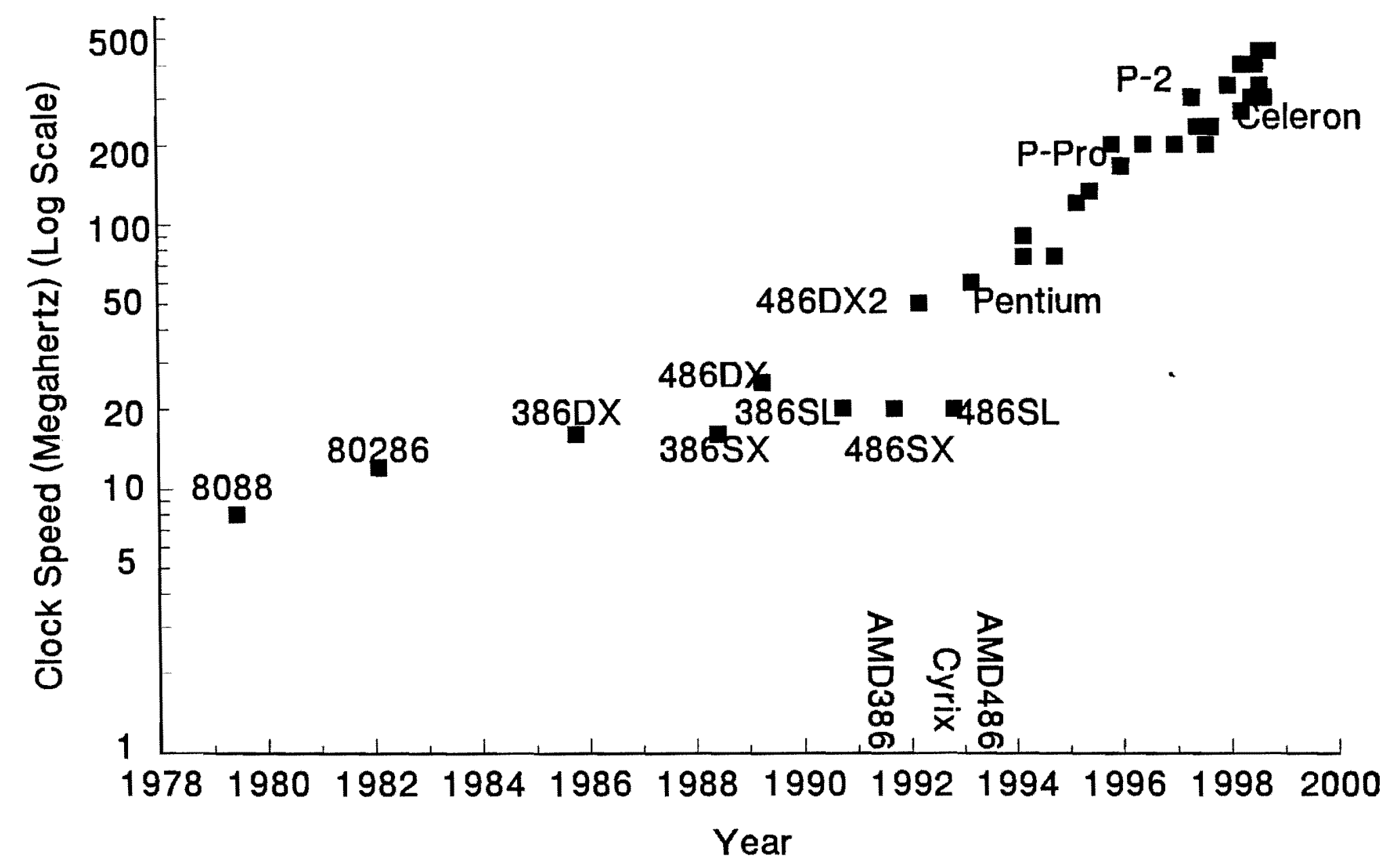




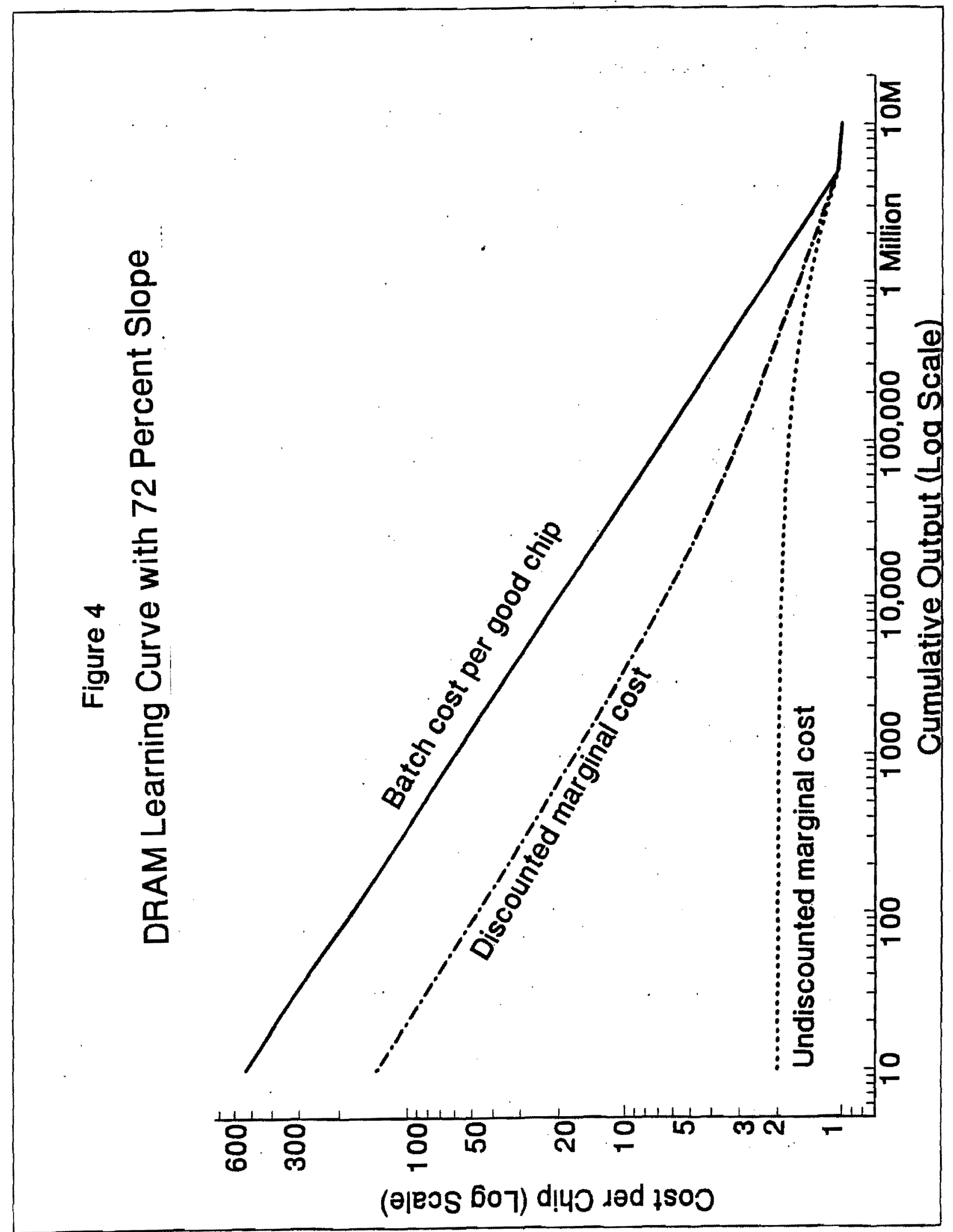


Figure 5

Approximate Life Cycle Cost Curve for Microprocessor Production Learning Curve Slope $=80$ Percent; Fixed Costs $=\$ 300$ Million

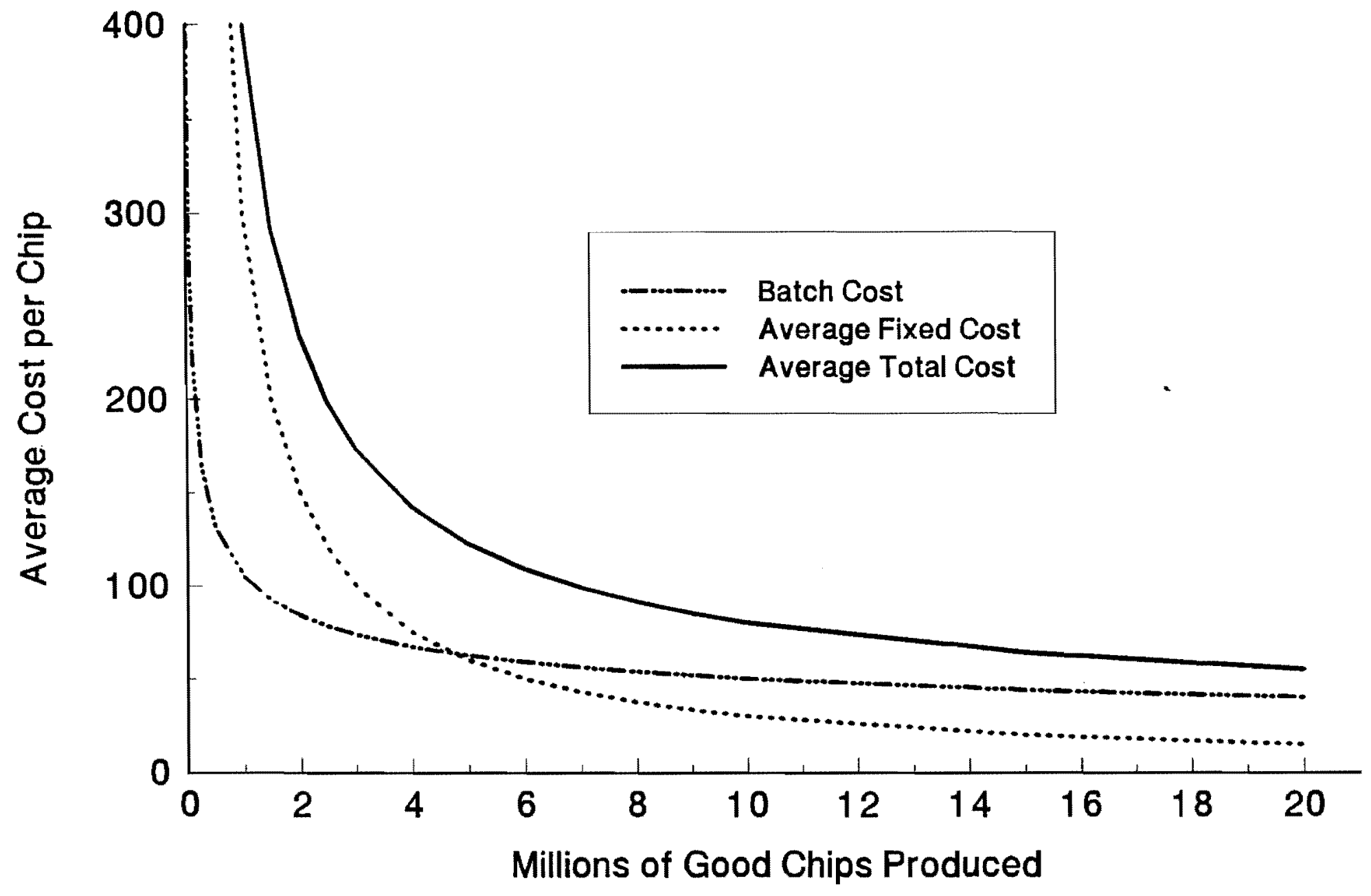


Figure 6

Timing of AMD's Progression Down an 80 Percent Learning Curve

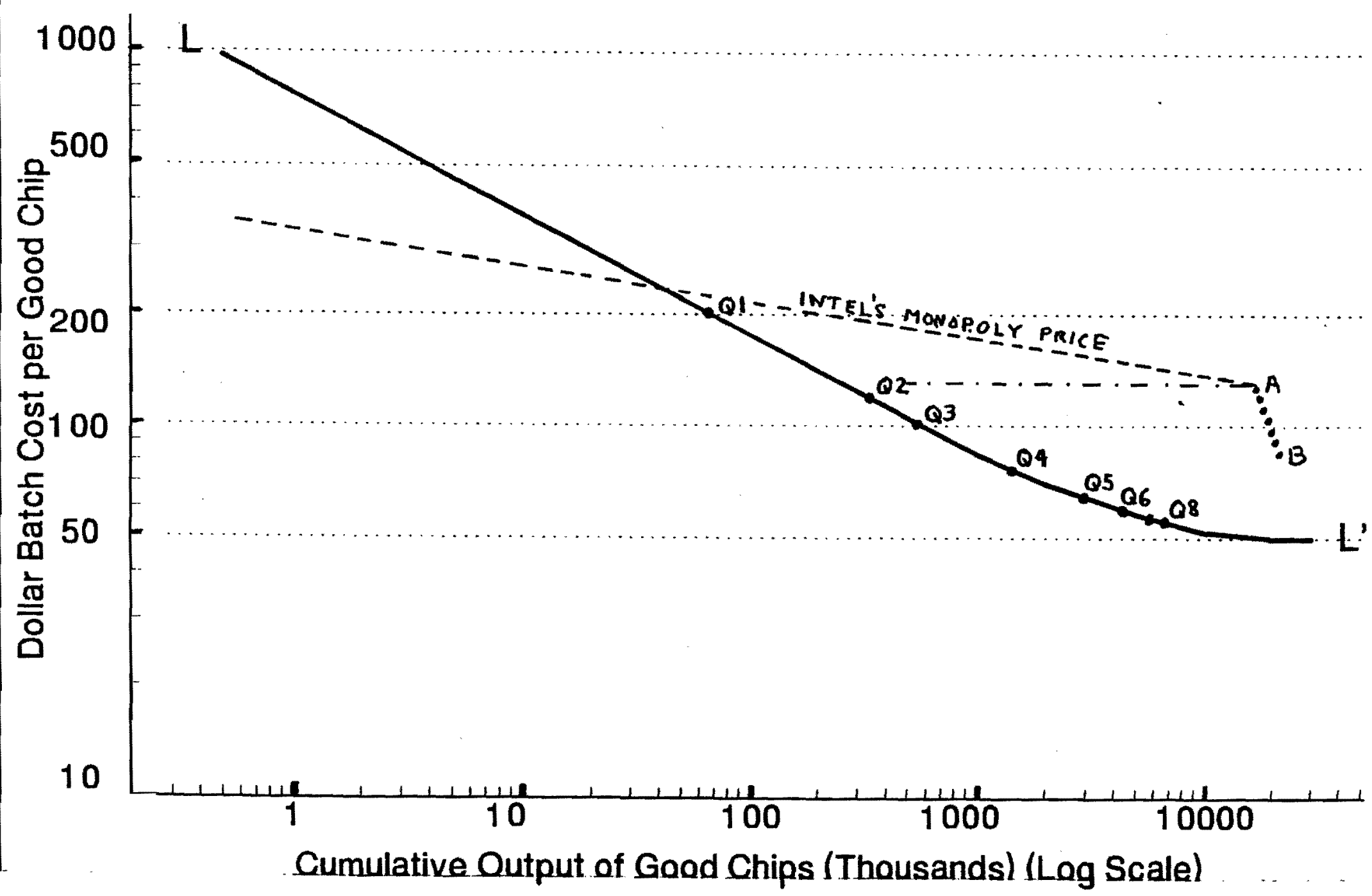

